\title{
Methylation of CHFR sensitizes esophageal squamous cell cancer to docetaxel and paclitaxel
}

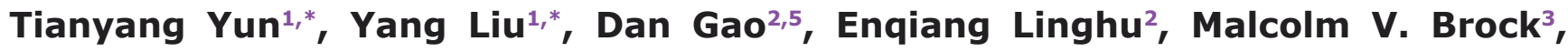 \\ Dongtao Yin ${ }^{1}$, Qimin Zhan ${ }^{4}$, James G. Herman ${ }^{3}$ and Mingzhou Guo ${ }^{2}$ \\ 1 Department of Thoracic Surgery, Chinese PLA General Hospital, Beijing, China \\ 2 Department of Gastroenterology \& Hepatology, Chinese PLA General Hospital, Beijing, China \\ ${ }^{3}$ Sidney Kimmel Comprehensive Cancer Center, Johns Hopkins University, Baltimore, Maryland, U.S.A \\ ${ }^{4}$ State Key Laboratory of Molecular Oncology, Cancer Institute and Hospital, Chinese Academy of Medical Sciences \& Peking \\ Union Medical College, Beijing, China \\ ${ }^{5}$ Medical College of NanKai University, Tianjin, China \\ * These authors contributed to this work equally \\ Correspondence to: Mingzhou Guo, email: mzguol@gmail.com \\ James G. Herman, email: hermaji@jhmi.edu
}

Keywords: DNA methylation, CHFR, esophageal squamous cell cancer, docetaxel, paclitaxel, chemo-sensitivity, 5-aza-2'-deoxycytidine

Received: September 17,2014 Accepted: December 30, $2014 \quad$ Published: December 31, 2014

This is an open-access article distributed under the terms of the Creative Commons Attribution License, which permits unrestricted use, distribution, and reproduction in any medium, provided the original author and source are credited.

\section{ABSTRACT}

Esophageal squamous cell carcinoma (ESCC) is one of the most common malignancies worldwide. Both genetic and epigenetic changes are involved in esophageal carcinogenesis. CHFR methylation has been found frequently in different cancers and is regarded as a marker of taxane sensitivity. CHFR methylation was found in $0 \%(0 / 16)$ of normal mucosa, $2.9 \%(1 / 34)$ of grade I dysplasia, $0 \%(0 / 8)$ of grade II dysplasia, $12.5 \%(1 / 8)$ of grade III dysplasia and $45 \%(49 / 109)$ of invasive cancer. When treated with docetaxel or paclitaxel, cell viability was lower in CHFR methylated esophageal cancer cells than in unmethylated cells $(p<0.05)$. No difference was found with either cisplatin or VP16 treatment in either group $(p>0.05)$. In CHFR methylated cells, treatment with docetaxel or paclitaxel resulted in almost all cells being suspended in G0/G1 phase of the cell cycle. After 5-AZ treatment, there was an increased fraction of CHFR-methylated cells in $S$ and G2/M phases $(p<0.05)$. In conclusion, CHFR is frequently methylated in ESCC and the expression of CHFR is regulated by promoter region methylation. CHFR methylation is a late stage event in ESCC. Methylation of CHFR sensitized ESCC cells to taxanes. 5-AZ may re-sensitize chemotherapy resistant in refractory tumors by inducing cell cycle phase re-distribution.

\section{INTRODUCTION}

Esophageal cancer is the eighth most common malignancy and the sixth most frequent cause of cancerrelated death worldwide $[1,2]$. More than 90 percent of esophageal cancers are either squamous cell or adenocarcinoma in histology [3]. The development of esophageal adenocarcinoma progresses from normal esophageal mucosa through intestinal metaplasia, to low grade and high grade dysplasia, and finally, to invasive cancer [4]. On the other hand, esophageal squamous cell carcinoma (ESCC) develops from normal esophageal epithelium through a hyperproliferative epithelium, to low grade and high grade dysplasia, and finally, to invasive cancer $[5,6]$. Although early surgical resection is still the best known approach to improve a patient's survival, most patients are diagnosed with advanced stage where chemotherapy is the most appropriate option. Currently, however, patients' prognosis with chemotherapy remains unsatisfactory because of side effects of chemotherapy 
and tumor acquired chemo-resistance [7]. Developing an effective chemo-sensitive marker will be a definite advance.

Accumulation of epigenetic changes in tumor suppressor genes is a well known event in human esophageal carcinogenesis [5, 8, 9]. DNA methylation may serve as marker for early cancer diagnosis, chemosensitivity as well as prognosis [7, 10-14]. The Checkpoint with forkhead and ring finger domains (CHFR) gene is an early mitotic checkpoint gene that functions as a key player in controlling chromosomal integrity [15]. CHFR knockout mice develop invasive lymphomas as well as solid tumors and are at increased susceptibility to chemical carcinogenesis [16]. Loss of CHFR expression and promoter region hypermethylation were found frequently in different cancers [17-20]. Methylation of CHFR was also regarded as a marker of taxane sensitivity in various cancers [21]. In 35 cases, no significant difference was found in the response of CHFR methylated and unmethylated esophageal cancer patients to the combined cisplatin and 5-fluorouracil therapy plus radiotherapy [22]. The methylation changes of CHFR during carcinogenesis and the sensitivity of esophageal squamous cell carcinoma to taxanes remain unclear.

\section{RESULTS}

\section{The Expression of CHFR was Silenced by Promoter Region Hypermethylation}

To detect the expression of CHFR in human esophageal cancer, 10 established esophageal cancer cell lines were employed [23]. Constant expression was found in KYSE30, KYSE140, KYSE180, KYSE450, KYSE520, TE7 and SEG1 cells while loss of expression was observed in KYSE70, KYSE150 and KYSE510 cells (Figure 1A). Methylation status was then determined by MSP. Complete methylation was found in KYSE70, KYSE150 and KYSE510 cells while KYSE30, KYSE140, KYSE180, KYSE450, KYSE520, TE7 and SEG1 cells were found to be without methylation (Figure 1B). CHFR expression was found to be inversely correlated to the gene's methylation status. Restoration of CHFR expression was induced by 5-aza-2'-deoxycytidine (5AZ) treatment in KYSE70, KYSE150 and KYSE510 cells (Figure 1A). These results suggest that the expression of CHFR was regulated by promoter region methylation in esophageal cancer cells.

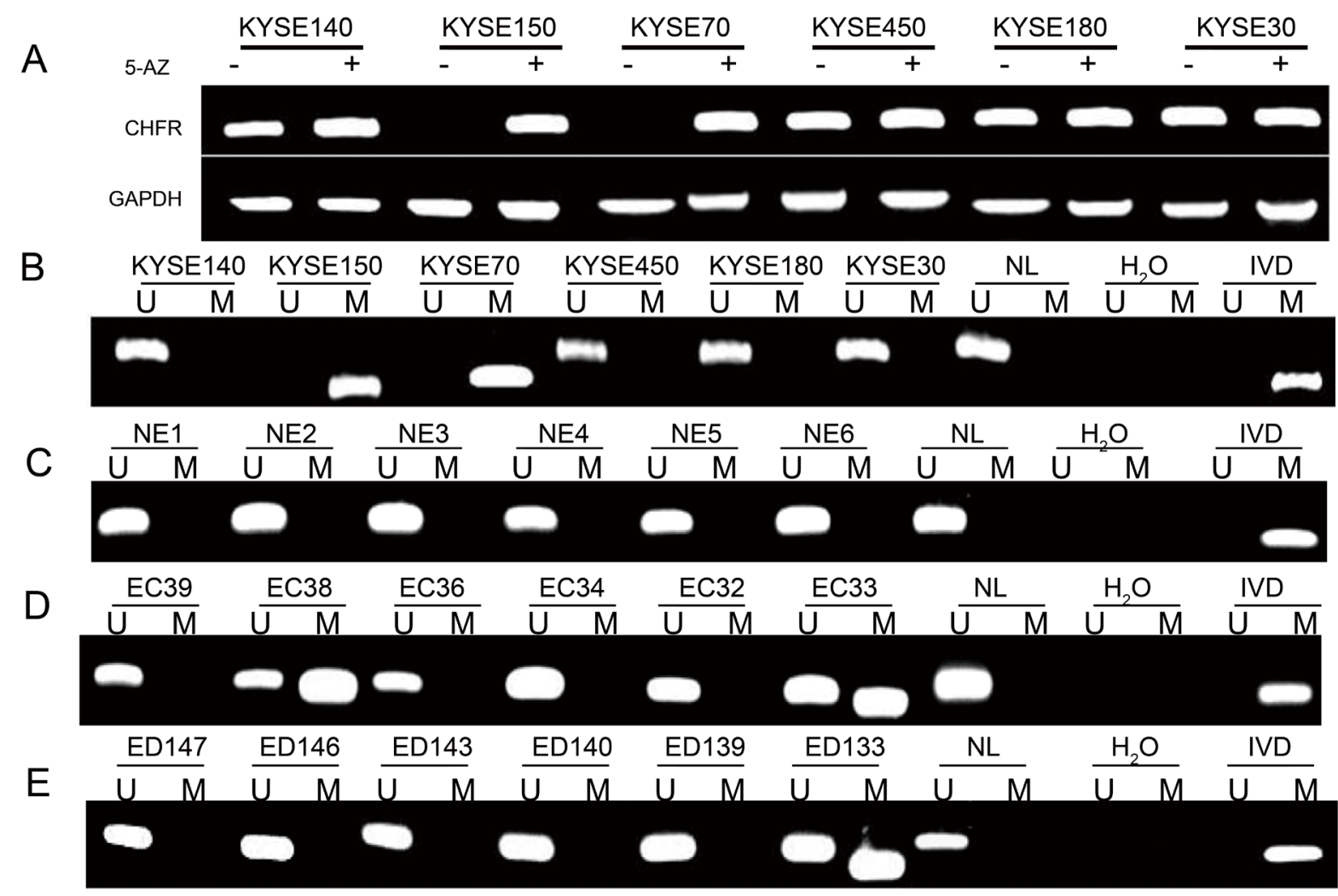

Figure 1: CHFR expression and methylation in esophageal cancer. A. The expression of CHFR was examined by RT-PCR. GAPDH: internal control. (-): without 5-AZ treated; (+) 5-AZ treatment . B. CHFR methylation status of human esophageal cancer cell lines. C. CHFR methylation status of human normal esophageal mucosa (NE). D. CHFR methylation status of primary human esophageal cancer(EC). E. CHFR methylation status of human esophageal dysplasia(ED) (U): unmethylated alleles; (M): methylated alleles. (IVD): in vitro methylated DNA, served as the methylation control; (NL): normal human peripheral lymphocytes, served as unmethylation control; (H2O): water, served as negative control. 
Table 1: MSP Results of Human Esophageal Tissue Samples

\begin{tabular}{|c|c|c|c|c|c|c|c|c|c|c|c|c|c|}
\hline \multicolumn{2}{|c|}{$\begin{array}{l}\text { NORMAL } \\
\text { ESOPHAGUS }\end{array}$} & \multicolumn{4}{|c|}{ ESOPHAGEAL DYSPLASIA } & \multicolumn{8}{|c|}{$\begin{array}{l}\text { ESOPHAGEAL SEQUAMOUS CELL } \\
\text { CARCINOMA }\end{array}$} \\
\hline & CHFR & Grade1 & CHFR & Grade2 & CHFR & & CHFR & & CHFR & & CHFR & & CHFR \\
\hline NE1 & & ED71 & & ED95 & & $\mathrm{ECl}$ & & EC36 & & EC71 & & EC106 & \\
\hline NE2 & & ED76 & & ED96 & & $\mathrm{EC} 2$ & & EC37 & & EC72 & & $\mathrm{EC} 107$ & \\
\hline NE3 & & ED97 & & ED100 & & $\mathrm{EC} 3$ & & EC38 & & $\mathrm{EC} 73$ & & EC108 & \\
\hline NE4 & & ED103 & & ED101 & & $\mathrm{EC} 4$ & & EC39 & & EC74 & & EC 109 & \\
\hline NE5 & & ED104 & & ED102 & & EC5 & & EC40 & & EC75 & & & $44.95 \% *$ \\
\hline NE6 & & ED106 & & ED107 & & $\mathrm{EC6}$ & & EC41 & & EC76 & & & \\
\hline NE7 & & ED112 & & ED116 & & EC7 & & EC42 & & EC77 & & & \\
\hline NE8 & & ED118 & & ED117 & & $\mathrm{EC} 8$ & & $\mathrm{EC} 43$ & & EC78 & & & \\
\hline NE9 & & ED119 & & Grade3 & & EC9 & & EC44 & & EC79 & & & \\
\hline NE10 & & ED120 & & $\mathrm{ED} 45$ & & $\mathrm{EC} 10$ & & EC45 & & EC80 & & & \\
\hline NE11 & & ED121 & & ED82 & & $\mathrm{EC} 11$ & & EC46 & & EC81 & & & \\
\hline NE12 & & ED122 & & ED90 & & $\mathrm{EC} 12$ & & EC47 & & EC 82 & & & \\
\hline $\mathrm{NE} 13$ & & ED123 & & ED93 & & $\mathrm{EC} 13$ & & EC48 & & EC83 & & & \\
\hline NE14 & & ED124 & & ED99 & & $\mathrm{EC} 14$ & & EC49 & & $\mathrm{EC} 84$ & & & \\
\hline NE15 & & ED125 & & ED113 & & $\mathrm{EC} 15$ & & EC50 & & EC85 & & & \\
\hline NE16 & & ED126 & & ED114 & & EC16 & & EC51 & & EC86 & & & \\
\hline & $0 \%$ & ED127 & & ED115 & & $\mathrm{EC} 17$ & & EC52 & & EC87 & & & \\
\hline & & ED128 & & Grade2+3 & $6.25 \%$ & $\mathrm{EC} 18$ & & EC53 & & EC88 & & & \\
\hline & & ED130 & & & & $\mathrm{EC} 19$ & & EC54 & & EC89 & & & \\
\hline & & ED131 & & & & $\mathrm{EC} 20$ & & EC55 & & EC90 & & & \\
\hline & & ED132 & & & & $\mathrm{EC} 21$ & & EC56 & & EC91 & & & \\
\hline & & ED133 & & & & $\mathrm{EC} 22$ & & EC57 & & EC92 & & & \\
\hline & & ED134 & & & & $\mathrm{EC} 23$ & & EC58 & & $\mathrm{EC} 93$ & & & \\
\hline & & ED135 & & & & $\mathrm{EC} 24$ & & EC59 & & EC94 & & & \\
\hline & & ED136 & & & & $\mathrm{EC} 25$ & & EC60 & & EC95 & & & \\
\hline & & ED138 & & & & $\mathrm{EC} 26$ & & EC61 & & EC96 & & & \\
\hline & & ED139 & & & & $\mathrm{EC} 27$ & & EC62 & & EC97 & & & \\
\hline & & ED140 & & & & $\mathrm{EC} 28$ & & EC63 & & EC98 & & & \\
\hline & & ED141 & & & & $\mathrm{EC} 29$ & & EC64 & & EC99 & & & \\
\hline & & ED143 & & & & EC30 & & EC65 & & EC100 & & & \\
\hline & & ED146 & & & & $\mathrm{EC} 31$ & & EC66 & & EC101 & & & \\
\hline & & ED147 & & & & $\mathrm{EC} 32$ & & EC67 & & EC102 & & & \\
\hline & & ED149 & & & & $\mathrm{EC} 33$ & & EC68 & & $\mathrm{EC} 103$ & & & \\
\hline & & ED129 & & & & EC34 & & EC69 & & EC104 & & & \\
\hline & & & $2.94 \%$ & & & EC35 & & EC70 & & EC105 & & & \\
\hline
\end{tabular}

$\mathrm{NE}=$ normal esophagus, $\mathrm{ED}=$ esophageal dysplasia, $\mathrm{EC}=$ esophageal cancer, Black grid= methylated alleles, White grid=unmethylated alleles. CHFR methylation is more frequent in EC than in $\mathrm{ED}\left(* P<0.01, x^{2}\right.$ test $)$. 


\section{CHFR Methylation is a Late Stage Event in the Development of Primary Squamous Esophageal Cell Cancer}

Epigenetic alterations have been shown to progress in frequency during esophageal carcinogenesis $[5,6]$. To determine if CHFR methylation may serve as an early detection marker of esophageal cancer, we examined the methylation of CHFR in normal esophageal mucosa, different grades of dysplasia, and in invasive cancer. Promoter region hypermethylation was found in $0 \%$ $(0 / 16)$ of normal mucosa, $2.9 \%(1 / 34)$ of grade I dysplasia, $0 \%(0 / 8)$ of grade II dysplasia, $12.5 \%(1 / 8)$ of grade III dysplasia and 44.95\% (49/109) of invasive esophageal cancer (Figure 1C,1D,1E, Table1). CHFR was more infrequently methylated in esophageal dysplasia than in invasive esophageal cancer $(p<0.01)$. This suggests that CHFR methylation was a late stage event of esophagus carcinogenesis. No association was found between methylation and age, gender, TNM stage, tumor size, differentiation and lymph node metastasis (all $\mathrm{p}>0.05$ ).

\section{Methylation of CHFR Sensitized Esophageal Cancer Cells to Taxanes}

Methylation of CHFR has been shown to sensitize different cancers to taxane treatment [24-26]. In a small study, no association was found between CHFR methylation and the sensitivity of esophageal cancer to cisplatin and 5-fluorouracil [22]. In this study, we compared the methylation status of CHFR and the sensitivity of esophageal cancer cells to paclitaxel, docetaxel, VP16 and cisplatin. No significant difference was found between the viability of unmethylated cells (KYSE140, KYSE450) and methylated cells (KYSE70, KYSE150) in cisplatin or VP16 treatment group ( Figure2, table2, all p>0.05). Methylated cells (KYSE70, KYSE150) were significantly more likely to undergo apoptosis than unmethylated cells (KYSE140, KYSE450) after paclitaxel or docetaxel treatment (Figure2, table2, all $\mathrm{p}<0.05$ ). The sensitivity of these CHFR methylated cells was further evaluated with or without 5-AZ treatment. In the cisplatin or VP16 treatment group, cell viability was unchanged with or without 5-AZ treatment (Figure2, table2, all $\mathrm{p}>0.05$ ). While in the paclitaxel and docetaxel treated groups, no significant difference was found between the methylated (KYSE70, KYSE150) and unmethylated cells (KYSE140, KYSE450) when treated with 5-AZ (Figure2, table2, all $\mathrm{p}>0.05$ ). These results further suggest that the methylation of CHFR sensitizes esophageal cancer cells to paclitaxel and docetaxel, while the restoration of CHFR expression with 5-AZ induces resistance to these chemotherapeutic agents.

\section{The Influence of Docetaxel or Paclitaxel on the Cell Cycle and Apoptosis Before and After 5-AZ treatment in CHFR Methylated Esophageal Cancer Cells}

CHFR methylation has been reported to sensitize cancer cells to taxanes. In our study, promoter region methylation sensitized KYSE70 and KYSE150 cells to docetaxel and paclitaxel. To understand the mechanism of promoter region methylation in cheom-sensitivity, we analyzed the cell cycle phase changes in CHFR methylated
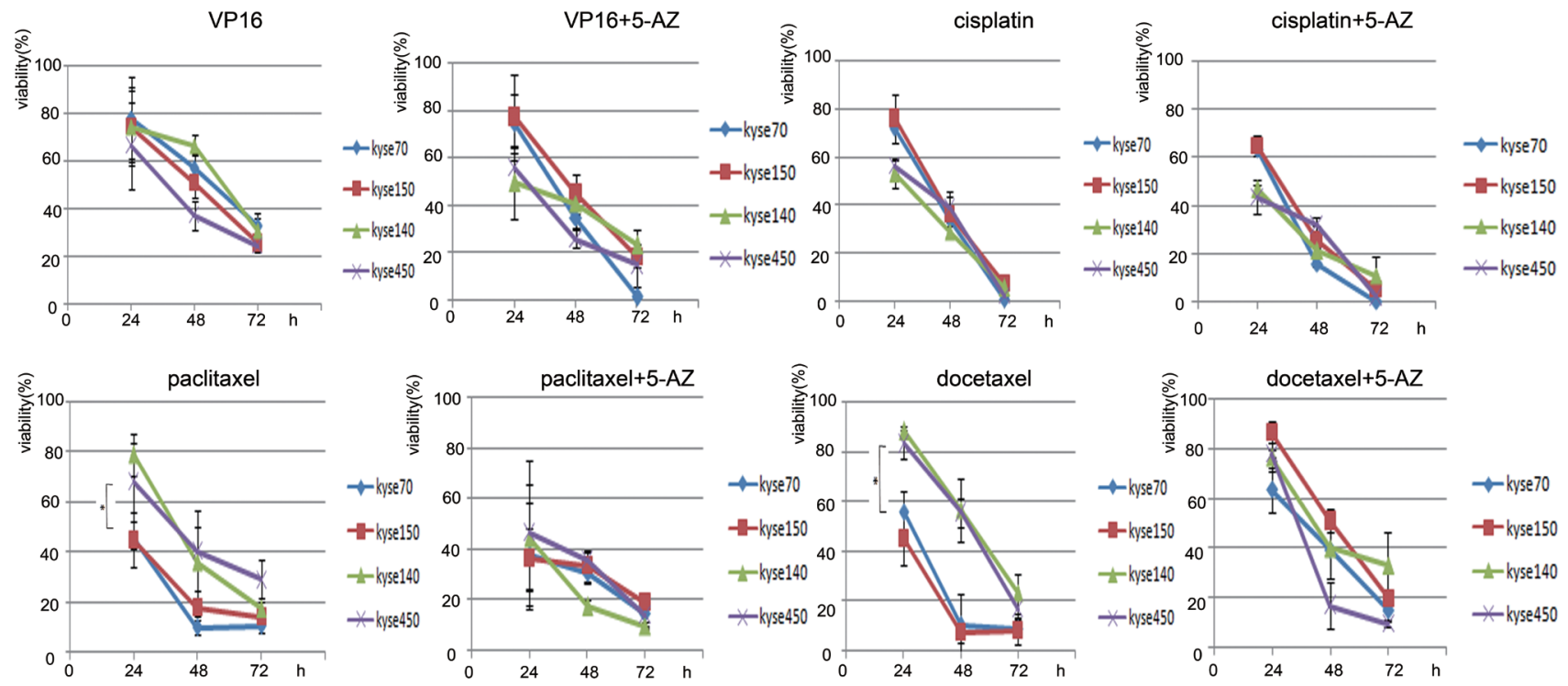

Figure 2: Cell viability in CHFR methylated (M) and unmethylated (U) esophageal cancer cells. The viability of CHFR methylated (KYSE70, KYSE150) and unmethylated (KYSE140, KYSE450) cell lines treated by VP16, cisplatin, paclitaxel or docetaxel, with or without 5-AZ treatment at $24 \mathrm{hrs}, 48 \mathrm{hrs}$ or $72 \mathrm{hrs}$ as shown in Table 2. 
Table 2: Cell viability(\%) in CHFR methylated (M) and unmethylated (U) esophageal cancer cells.

\begin{tabular}{|c|c|c|c|c|c|c|c|c|c|}
\hline \multicolumn{2}{|l|}{$24 \mathrm{hrs}$} & \multicolumn{2}{|c|}{ VP16 (\%) } & \multicolumn{2}{|c|}{ cisplatin (\%) } & \multicolumn{2}{|c|}{ paclitaxel $(\%)$} & \multicolumn{2}{|c|}{ Docetaxel (\%) } \\
\hline Cell line & CHFR & 5-AZ(-) & 5-AZ(+) & 5-AZ(-) & 5-AZ(+) & 5-AZ(-) & 5-AZ(+) & 5-AZ(-) & 5-AZ $(+)$ \\
\hline KYSE70 & $\mathrm{M}$ & \begin{tabular}{|l|}
$78.02 \pm$ \\
17.17
\end{tabular} & \begin{tabular}{|l|}
$74.57 \pm$ \\
12.22
\end{tabular} & $72.05 \pm 6.29$ & \begin{tabular}{|l|}
$63.15 \pm$ \\
1.39
\end{tabular} & $45.07 \pm 11.08$ & \begin{tabular}{|l|}
$37.38 \pm$ \\
21.10
\end{tabular} & \begin{tabular}{|l|}
$56.01 \pm$ \\
7.89
\end{tabular} & \begin{tabular}{|l|}
$63.27 \pm$ \\
8.66
\end{tabular} \\
\hline KYSE150 & $\mathrm{M}$ & \begin{tabular}{|l|}
$74.49 \pm$ \\
15.18 \\
\end{tabular} & \begin{tabular}{|l|}
$77.27 \pm$ \\
18.01 \\
\end{tabular} & $76.01 \pm 994$ & \begin{tabular}{|l|}
$64.73 \pm$ \\
4.37 \\
\end{tabular} & $44.87 \pm 3.70$ & \begin{tabular}{|l}
$36.33 \pm$ \\
11.81 \\
\end{tabular} & \begin{tabular}{|l|l}
$44.94 \pm$ \\
10.53 \\
\end{tabular} & \begin{tabular}{|l|}
$86.54 \pm$ \\
4.32 \\
\end{tabular} \\
\hline KYSE140 & $\mathrm{U}$ & \begin{tabular}{|l|}
$74.42 \pm$ \\
16.43 \\
\end{tabular} & \begin{tabular}{|l|}
$49.34 \pm$ \\
14.85 \\
\end{tabular} & $52.97 \pm 5.69$ & \begin{tabular}{|l}
$46.53 \pm$ \\
2.35
\end{tabular} & $78.75 \pm 8.60$ & \begin{tabular}{|l}
$44.34 \pm$ \\
20.90 \\
\end{tabular} & \begin{tabular}{|l|}
$88.05 \pm$ \\
1.74 \\
\end{tabular} & \begin{tabular}{|l|}
$76.53 \pm$ \\
6.05
\end{tabular} \\
\hline KYSE450 & $\mathrm{U}$ & \begin{tabular}{|l|}
$66.6 \pm$ \\
18.12 \\
\end{tabular} & $\begin{array}{l}55.55 \pm \\
9.46 \\
\end{array}$ & $56.12 \pm 3.51$ & \begin{tabular}{|l}
$43.64 \pm$ \\
7.14 \\
\end{tabular} & $67.95 \pm 15.77$ & $\begin{array}{l}46.4 \pm \\
28.80 \\
\end{array}$ & $83.1 \pm 5.77$ & \begin{tabular}{|l|}
$77.82 \pm$ \\
1.39 \\
\end{tabular} \\
\hline \multicolumn{2}{|l|}{$48 \mathrm{hrs}$} & \multicolumn{2}{|c|}{ VP16 (\%) } & \multicolumn{2}{|l|}{ cisplatin $(\%)$} & \multicolumn{2}{|c|}{ paclitaxel (\%) } & \multicolumn{2}{|c|}{ Docetaxel (\%) } \\
\hline Cell line & CHFR & 5-AZ(-) & $5-\mathrm{AZ}(+)$ & 5-AZ(-) & $5-\mathrm{AZ}(+)$ & 5-AZ(-) & $5-\mathrm{AZ}(+)$ & 5-AZ(-) & $5-\mathrm{AZ}(+)$ \\
\hline KYSE70 & $\mathrm{M}$ & $\begin{array}{l}57.41 \pm \\
5.95\end{array}$ & $34.7 \pm 4.61$ & $34.19 \pm 1.53$ & $\begin{array}{l}15.97 \pm \\
1.06\end{array}$ & $9.86 \pm 2.68$ & $\begin{array}{l}30.73 \pm \\
4.13\end{array}$ & $\begin{array}{l}9.94 \pm \\
12.70 \\
\end{array}$ & $\begin{array}{l}39.19 \pm \\
11.63 \\
\end{array}$ \\
\hline KYSE150 & M & \begin{tabular}{|l|}
$50.88 \pm$ \\
6.02 \\
\end{tabular} & $44.8 \pm 7.95$ & $36.25 \pm 9.66$ & $\begin{array}{l}25.52 \pm \\
6.02\end{array}$ & $17.63 \pm 3.51$ & $\begin{array}{l}33.29 \pm \\
5.76\end{array}$ & $7.39 \pm 3.92$ & $\begin{array}{l}51.13 \pm \\
4.81\end{array}$ \\
\hline KYSE140 & $\mathrm{U}$ & \begin{tabular}{|l}
$66.75 \pm$ \\
14.85 \\
\end{tabular} & $\begin{array}{l}40.65 \pm \\
4.61 \\
\end{array}$ & $28.94 \pm 2.44$ & $\begin{array}{l}21.13 \pm \\
1.59 \\
\end{array}$ & $35.84 \pm 14.38$ & $\begin{array}{l}17.16 \pm \\
2.78\end{array}$ & \begin{tabular}{|l|}
$56.57 \pm$ \\
12.57 \\
\end{tabular} & \begin{tabular}{|l|}
$39.88 \pm$ \\
12.32 \\
\end{tabular} \\
\hline KYSE450 & $\mathrm{U}$ & \begin{tabular}{|l|}
$37.08 \pm$ \\
9.46 \\
\end{tabular} & \begin{tabular}{|l|}
$25.94 \pm$ \\
3.64 \\
\end{tabular} & $38.99 \pm 4.60$ & \begin{tabular}{|l|}
$31.65 \pm$ \\
3.65 \\
\end{tabular} & $40.36 \pm 15.95$ & \begin{tabular}{|l|}
$35.53 \pm$ \\
3.87 \\
\end{tabular} & \begin{tabular}{|l|}
$55.62 \pm$ \\
5.71 \\
\end{tabular} & $17 \pm 9.47$ \\
\hline \multicolumn{2}{|l|}{$72 \mathrm{hrs}$} & \multicolumn{2}{|c|}{ VP16 (\%) } & \multicolumn{2}{|l|}{ cisplatin $(\%)$} & \multicolumn{2}{|l|}{ paclitaxel $(\%)$} & \multicolumn{2}{|c|}{ Docetaxel $(\%)$} \\
\hline Cell line & CHFR & 5-AZ(-) & 5-AZ(+) & 5-AZ(-) & $5-\mathrm{AZ}(+)$ & 5-AZ(-) & $5-\mathrm{AZ}(+)$ & 5-AZ(-) & $5-\mathrm{AZ}(+)$ \\
\hline KYSE70 & M & \begin{tabular}{|l|}
$32.82 \pm$ \\
5.24 \\
\end{tabular} & $1.14 \pm 1.63$ & $1.05 \pm 0.88$ & $0.42 \pm 3.25$ & $10.47 \pm 2.42$ & \begin{tabular}{|l|}
$14.73 \pm$ \\
5.41 \\
\end{tabular} & $8.42 \pm 2.55$ & \begin{tabular}{|l|}
$14.88 \pm$ \\
4.45 \\
\end{tabular} \\
\hline KYSE150 & M & $\begin{array}{l}25.45 \pm \\
2.73 \\
\end{array}$ & $\begin{array}{l}18.15 \pm \\
4.29\end{array}$ & $7.62 \pm 2.60$ & $5.3 \pm 1.07$ & $14.04 \pm 2.27$ & $\begin{array}{l}18.96 \pm \\
0.54\end{array}$ & $8.23 \pm 5.37$ & $\begin{array}{l}20.25 \pm \\
2.93 \\
\end{array}$ \\
\hline KYSE140 & $\mathrm{U}$ & \begin{tabular}{|l|}
$31.08 \pm$ \\
5.07 \\
\end{tabular} & $\begin{array}{l}22.97 \pm \\
7.03 \\
\end{array}$ & $5.54 \pm 0.93$ & $\begin{array}{l}10.83 \pm \\
7.86 \\
\end{array}$ & $17.2 \pm 2.83$ & $9.77 \pm 1.56$ & \begin{tabular}{|l|}
$23.12 \pm$ \\
8.04 \\
\end{tabular} & \begin{tabular}{|l|}
$32.89 \pm$ \\
13.36 \\
\end{tabular} \\
\hline KYSE450 & $\mathrm{U}$ & $\begin{array}{l}24.63 \pm \\
2.75\end{array}$ & \begin{tabular}{|l}
$14.81 \pm$ \\
9.24
\end{tabular} & $2.47 \pm 0.58$ & $2.02 \pm 0.91$ & $29.1 \pm 7.60$ & $\begin{array}{l}14.03 \pm \\
4.42 \\
\end{array}$ & $\begin{array}{l}16.85 \pm \\
4.45 \\
\end{array}$ & $9.62 \pm 1.63$ \\
\hline
\end{tabular}

VP16, cisplatin, paclitaxel or docetaxel treated cells, with(+) or without(-) 5-AZ treatment in $24 \mathrm{hrs}$, $48 \mathrm{hrs}$ or $72 \mathrm{hrs}$. Each experiment was repeated three times.

esophageal cancer cell lines before and after docetaxel/ paclitaxel treatment, with or without 5-AZ. In paclitaxel treated KYSE70 cells, cell cycle phase distributions before and after 5-AZ treatment were as follows: $100.00 \%$ vs. $39.86 \%$ in $\mathrm{G} 0 / \mathrm{G} 1$ phase, $0.00 \%$ vs. $35.83 \%$ in $\mathrm{S}$ phase, $0.00 \%$ vs. $24.31 \%$ in $\mathrm{G} 2 / \mathrm{M}$ phase. In docetaxel treated KYSE70 cells, cell cycle phase distributions before and after 5-AZ treatment were as follows: $98.25 \%$ vs. $37.90 \%$ in $\mathrm{G} 0 / \mathrm{G} 1$ phase. $1.75 \%$ vs. $38.04 \%$ in $\mathrm{S}$ phase, $0.00 \%$ vs. $24.06 \%$ in G2/M phase. In paclitaxel treated KYSE150 cells, cell cycle phase distributions before and after 5-AZ treatment were as follows: $98.11 \%$ vs. $36.92 \%$ in G0/G1 phase, $1.89 \%$ vs. $19.14 \%$ in S phase, $0.00 \%$ vs. $43.94 \%$ in G2/M phase. In docetaxel treated KYSE150 cells, cell cycle phase distributions before and after 5-AZ treatment were as follows: $100.00 \%$ vs. $21.06 \%$ in $\mathrm{G} 0 / \mathrm{G} 1$ phase, $0.00 \%$ vs. $17.85 \%$ in S phase, $0.00 \%$ vs. $61.09 \%$ in $\mathrm{G} 2 / \mathrm{M}$ phase. In CHFR methylated esophageal cancer cells, under docetaxel or paclitaxel treatment, $\mathrm{S}$ and G2/M phase cells were increased with the treatment of 5-AZ (Figure3, all $\mathrm{p}<0.05$ ). These results may partially explain the mechanism by which 5-AZ can overcome chemotherapy resistance in refractory solid tumors [27]. Apoptosis was analyzed before and after docetaxel/paclitaxel treatment in KYSE70 and KYSE150 cells. The ratio of apoptosis was $16.78 \pm 5.42 \%$ vs. baseline of $4.39 \pm 0.56 \%$ and 22.45 $\pm 3.49 \%$ vs. $4.39 \pm 0.56 \%$ for docetaxel or paclitaxel ( both $\mathrm{P}<0.05)$ in KYSE70 cells. In KYSE150 cells, the apoptotic rate was $10.97 \pm 0.61 \% v s$. baseline of $5.16 \pm$ $0.51 \%$ and $15.78 \pm 1.09$ vs. $5.16 \pm 0.51 \%$ for docetaxel or paclitaxel (all $\mathrm{P}<0.05$ ) (Fig.4). No significant changes were found between the docetaxel/paclitaxel treatment groups and the docetaxel/paclitaxel combined with 5-AZ treatment groups.

\section{DISCUSSION}

Accumulation of genetic and epigenetic changes 
KYSE70
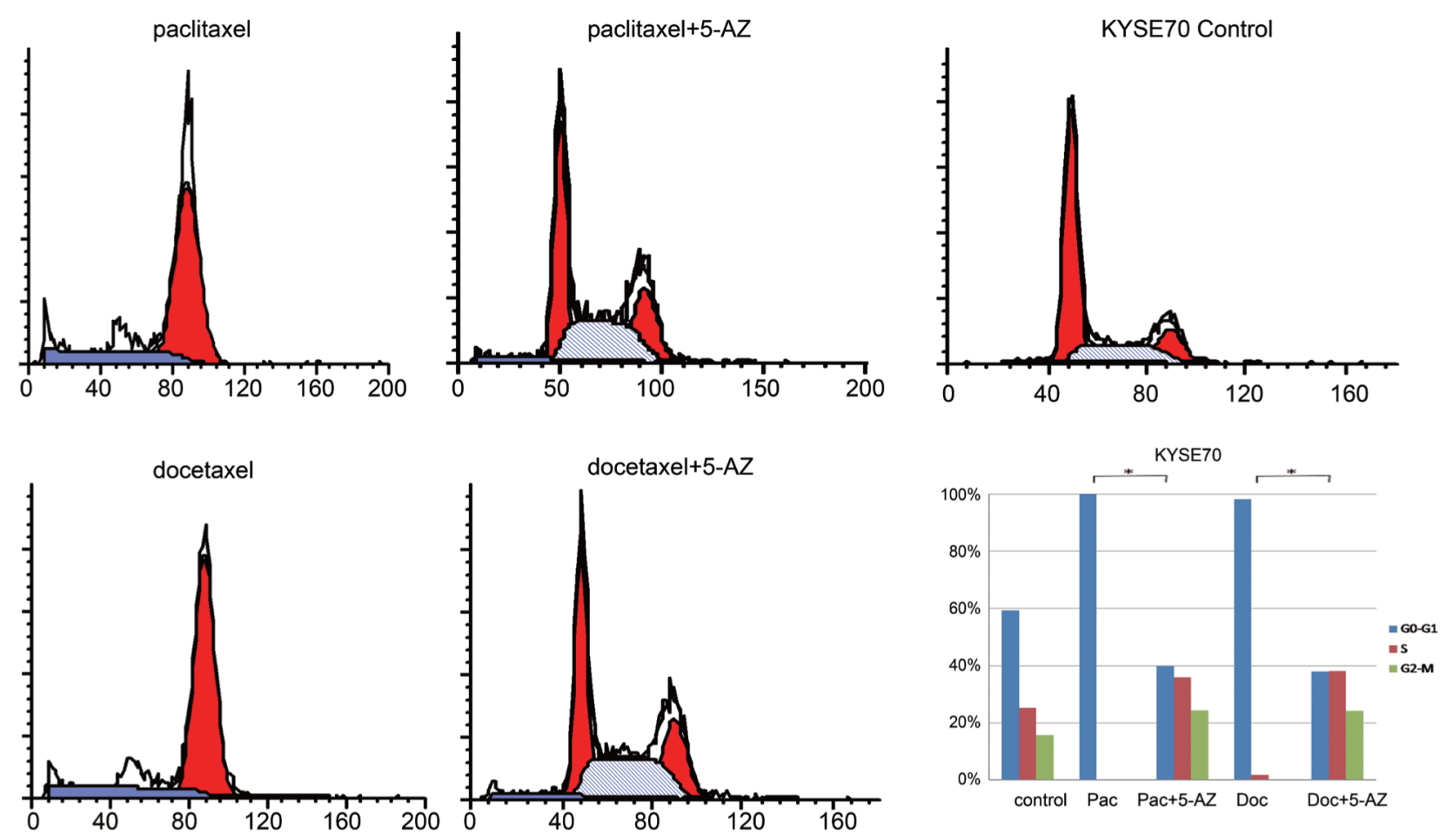

KYSE150
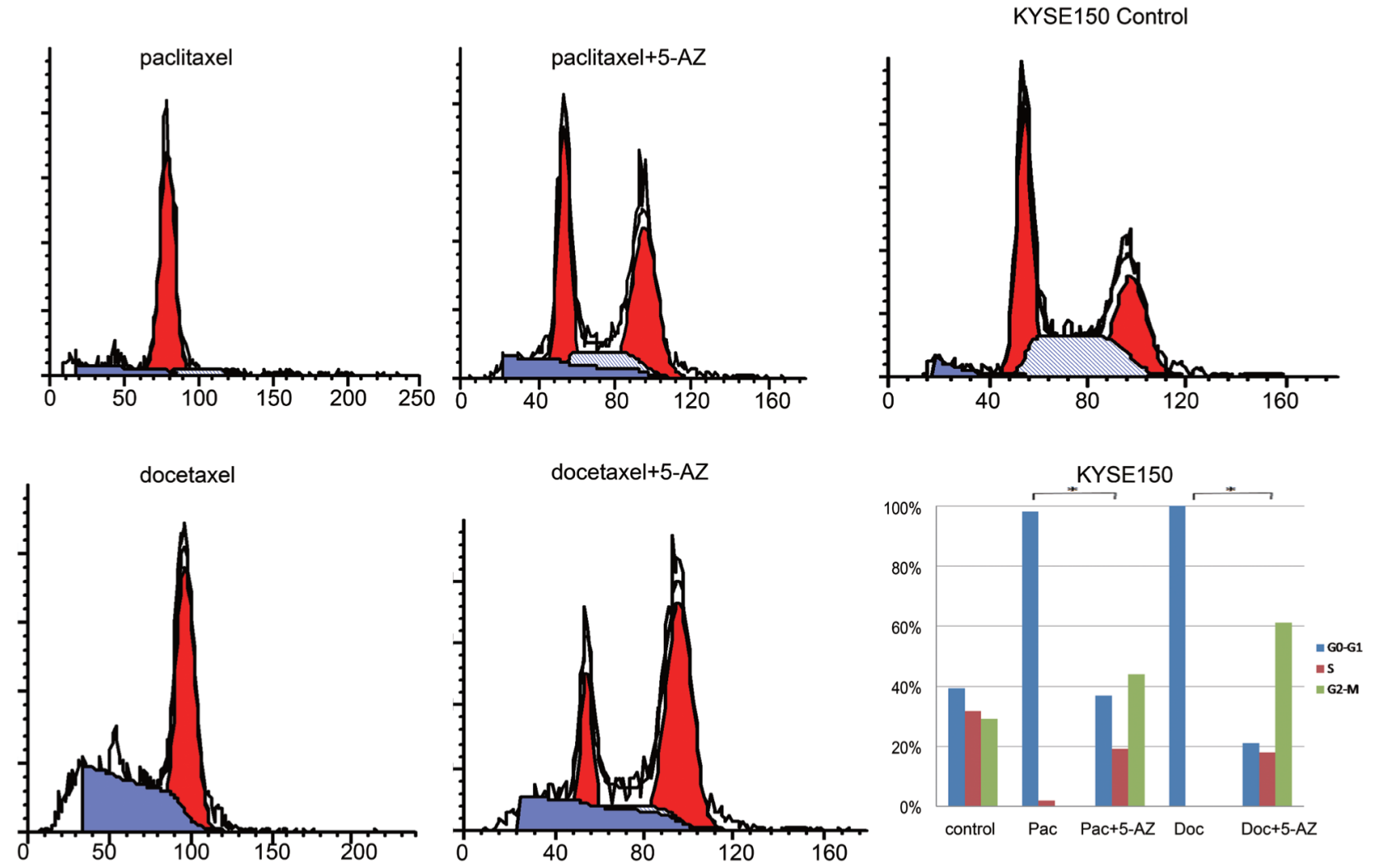

Figure3: The flow cytometric assay shows the cell phase distribution in methylated esophageal cancer cells (KYSE70 and KYSE150) Pac: paclitaxel; Doc: docetaxel 
has been found in the development of various cancers, including esophageal cancer [28-30]. The methylation status during the carcinogenesis of esophageal squamous cell, however, remains unclear. In this study, we found that CHFR is infrequently methylated early in the esophageal carcinogenesis, but becomes more frequently methylated during the advanced cancer stage. It suggests that CHFR methylation is a late stage marker of esophageal squamous cell carcinoma. Methylation of CHFR has been regarded as a chemo-sensitive marker in various cancers [24-26]. We found CHFR methylation sensitizes esophageal cancer cells to docetaxel and paclitaxel, and 5-AZ induces chemoresistance of CHFR methylated cells to docetaxel and paclitaxel. These results suggest that CHFR methylation is a taxane sensitive marker in human esophageal squamous cancer. There are a few reports about the ability of epigenetic therapy to undo chemoresistance and re-sensitize refractory tumors to specific chemotherapy agents [27, 31-33]. But the definitive mechanism remains to be elucidated. To
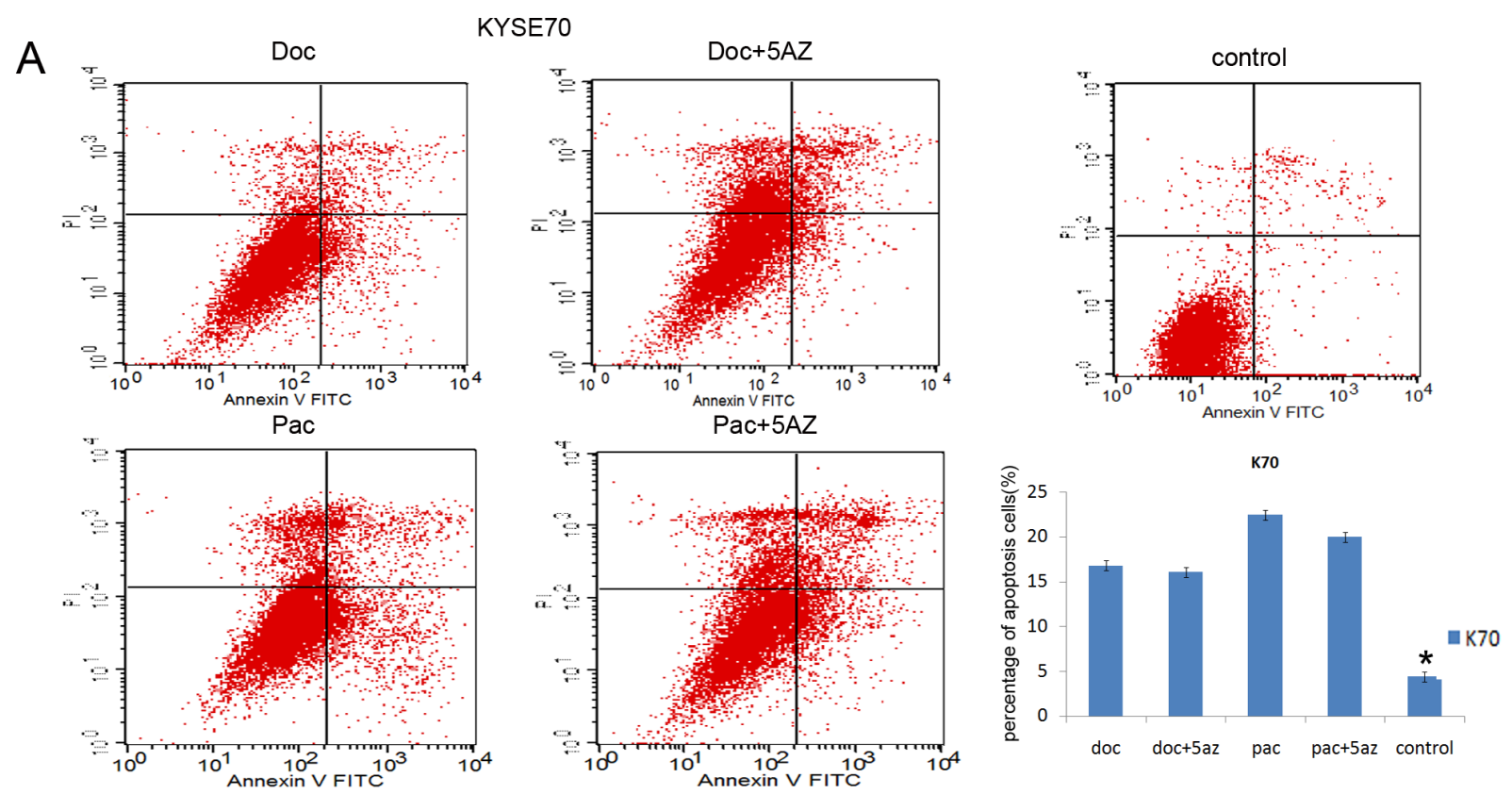

B

KYSE150
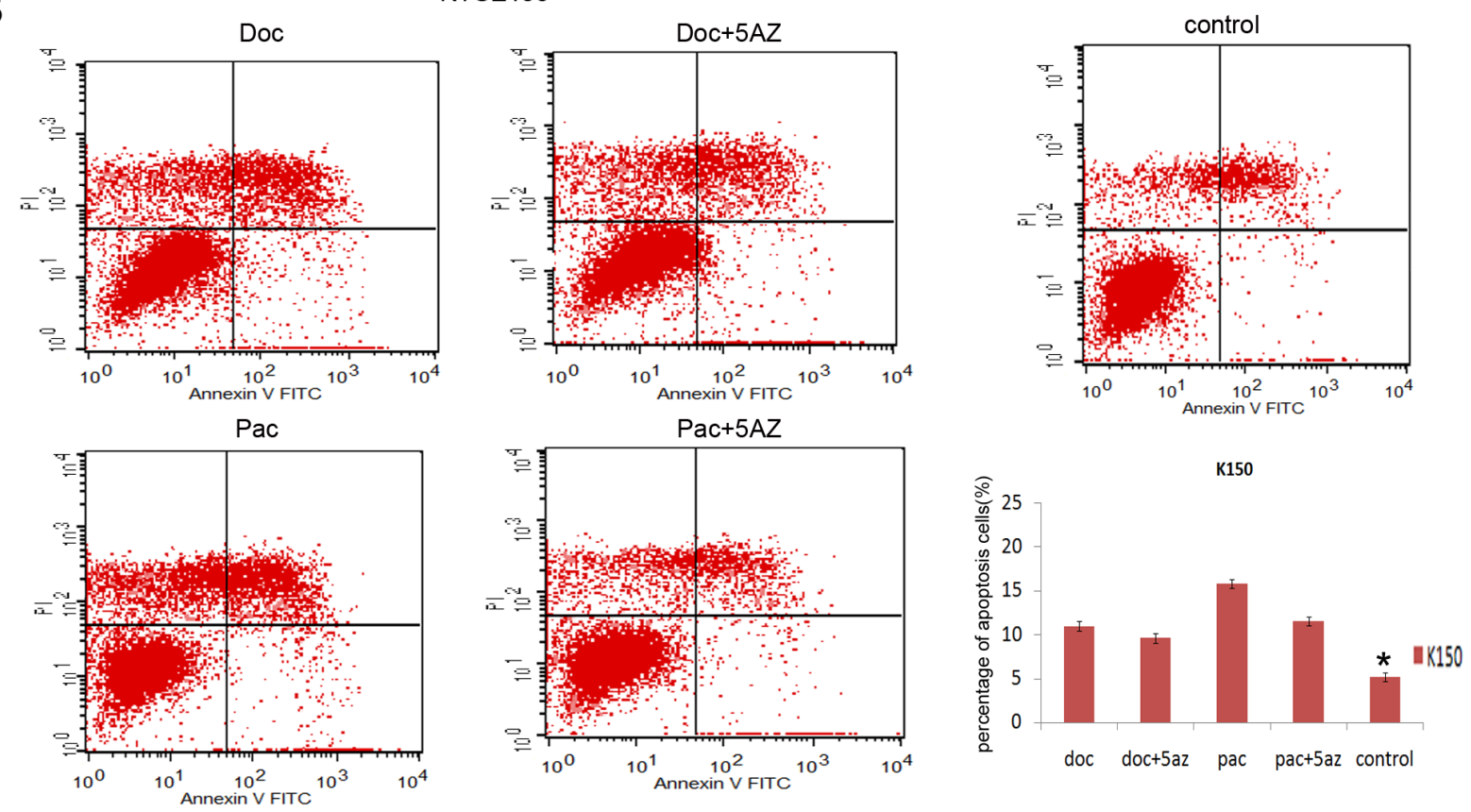

Figure 4: Effect of paclitaxel and docetaxel on cell apoptosis Percentage of KYSE70 and KYSE150 apoptotic cells before and after paclitaxel or docetaxel treatment, with or without 5-AZ treatment. 
answer this question, we analyzed cell cycle distributions in docetaxel and paclitaxel treated esophageal cancer cells with or without 5-AZ treatment. After docetaxel or paclitaxel treatment, almost all viable cells were in G0/ G1 phase. When docetaxel or paclitaxel is combined with 5-AZ treatment, S and G2/M phase cells were increased. This result may be interpreted as a partial explanation for the mechanism by which epigenetic therapy re-sensitizes chemotherapy resistant, refractory tumors. Microtubule inhibitors, such as docetaxel and paclitaxel, disrupt normal microtubule dynamics during cell division by binding to the beta-tubulin subunits. This can lead to a failure of microtubule separation and apoptosis. As CHFR is able to block entry into prophase until chromosomal alignment is restored, CHFR inhibits the effect of taxanes [21, 34]. Accordingly, cells expressing CHFR are more viable upon treatment with microtubule inhibitors compared to cells not expressing CHFR [21, 34]. In our study, silencing CHFR by promoter region hypermethylation sensitized esophageal cancer cells to docetaxel and paclitaxel. In addition, CHFR expression was induced by 5-AZ in CHFR methylated esophageal cancer cells. We also observed that $\mathrm{S}$ and $\mathrm{G} 2 / \mathrm{M}$ phase cells were increased in docetaxel and paclitaxel treated esophageal cancer cells when combined with 5-AZ treatment. The ability of 5-AZ to re-sensitize refractory tumors to chemotherapy may be due to the ability of 5-AZ in some cancers to change the cell cycle phase.

In conclusion, CHFR is frequently methylated in human esophageal squamous cell carcinoma and the expression of CHFR is regulated by promoter region methylation. Methylation of CHFR is a late stage event in esophageal cancer. Methylation of CHFR sensitized esophageal cancer cells to docetaxel and paclitaxel. Finally, 5-AZ may re-sensitize chemotherapy resistant refractory tumors by inducing cell cycle phase redistribution.

\section{MATERIAL \& METHODS}

\section{Human tissue samples and cell lines}

Ten human esophageal cancer cell lines (KYSE30, KYSE140, KYSE180, KYSE450, KYSE520, TE7, SEG1, KYSE70, KYSE150 and KYSE510) were used in this study [23]. All the esophageal cancer cell lines were established from primary esophageal cancer and maintained in 90\% RPMI 1640 (Invitrogen, CA, USA), supplemented with $10 \%$ fetal bovine serum and antibiotics. Sixteen cases of normal esophageal mucosa and 109 cases of invasive esophageal squamous cancer specimens were collected as fresh frozen tissue from the Chinese General PLA Hospital and kept at $-80^{\circ} \mathrm{C}$. All tissue samples were classified by TNM staging, stage
I $(n=2)$, stage II $(n=65)$, stage III $(n=41)$ and stage IV $(n=1)$. Themedian age of the patients was $59.35 \pm 8.91$. Fifty cases of paraffin-embedded esophageal squamous dysplasia samples, including grade $1(n=34)$, grade 2 $(n=8)$, and grade $3(n=8)$ specimens, were collected from the Second Teaching Hospital, Zhengzhou University. All tissues sample were collected according to the approved guidelines of the Institutional Review Boards of both the Chinese PLA General Hospital and the Second Teaching Hospital, Zhengzhou University.

\section{5-aza-2'-deoxycytidine (5-AZ) treatment}

Esophageal cancer cells were split to a low density (30\% confluence) $12 \mathrm{~h}$ before treatment. Cells were treated with 5-AZ (Sigma, St. Louis, MO, USA) at a concentration of $2 \mu \mathrm{M}$ in the growth medium, which was exchanged every $24 \mathrm{~h}$ for a total of $96 \mathrm{~h}$ treatment. At the end of the treatment course, RNA was isolated as described below.

\section{RNA isolation and semi-quantitative RT-PCR}

Total RNA was isolated by Trizol reagent (Invitrogen, Carlsbad, USA). RNA quality and quantity were evaluated by $1 \%$ Agarose gel electrophoresis and spectrophotometric analysis. Semi-quantitative reverse transcription-PCR (RT-PCR) was performed as described previously[35]. RT-PCR primers were as follows: 5'-GGCGAGAGCGTTCCTCCAGTTG-3' (F); 5'-GCATGTCAGCGTCTCCTCCATCTTG-3'(R).

\section{DNA Extraction, Methylation-Specific PCR (MSP)}

Genomic DNA of esophageal cancer cells and tissue samples were extracted by the proteinase K method. MSP was performed as described previously [5, 36, 37]. Primers for MSP were designed around the transcription start site. The sequences of the MSP primers were as follows: 5'-GATTGTAGTTATTTTTGTGATTTGTAGGTGAT$3^{\prime}(\mathrm{UF})$, 5'-AACTAAAACAAAACCAAAAATAACCCACA3'(UR), 5'-GTTATTTTCGTGATTCGTAGGCGAC$3^{\prime}(\mathrm{MF})$ and 5'-CGAAACCGAAAATAACCCGCG$3^{\prime}(\mathrm{MR})$. The amplification was performed as follows: an initial step at $95^{\circ} \mathrm{C}$ for $5 \mathrm{~min}$; then 35 cycles of $95^{\circ} \mathrm{C}$ for $30 \mathrm{~s}, 60^{\circ} \mathrm{C}$ for $30 \mathrm{~s}$ and $72^{\circ} \mathrm{C}$ for $30 \mathrm{~s}$; the final extension step at $72^{\circ} \mathrm{C}$ for $5 \mathrm{~min}$.

Meanwhile, for paraffin-embedded esophageal dysplasia, we first performed a NESTED-PCR, and then carried out MSP using the NESTED-PCR product. External primer sequences were: CHFR Flank-F: 5'-TTTTYGTTTTTTTTGTTTTAATATAATATGG-3' 
CHFR

Flank-R:

5'-CRCRCACCAAAAACRACAACRAAAAC-3'. The

PCR products were then diluted with $\mathrm{H}_{2} \mathrm{O}$ to $1: 1,000$ and $2 \mathrm{ul}$ was used as template for each $25 \mathrm{ul}$ reaction MSP analysis. PCR cycle conditions were as follows: $95^{\circ} \mathrm{C}$ for $5 \mathrm{~min}$; then 30 cycles of $95^{\circ} \mathrm{C}$ for $30 \mathrm{~s}, 60^{\circ} \mathrm{C}$ for $30 \mathrm{~s}$ and $72^{\circ} \mathrm{C}$ for 30 s; the final extension step at $72^{\circ} \mathrm{C}$ for $5 \mathrm{~min}$.

\section{Cell viability assay}

KYSE70, KYSE 150, KYSE 140 and KYSE 450 were suspended at $5 \times 10^{3}$ cells per well and subcultured in a 96-well plate. These cell lines were prepared in two groups. All four cell lines were included in each group and each group had three time points $(24 \mathrm{~h}, 48 \mathrm{~h}$ and $72 \mathrm{~h}$ ). After passage for $16 \mathrm{~h}$, group 1 was treated with $10 \mu \mathrm{g} / \mathrm{mL}$ paclitaxel (Pac), $18.4 \mu \mathrm{g} / \mathrm{ml}$ docetaxel (Doc), $25 \mu \mathrm{g} / \mathrm{ml} \mathrm{VP} 16$, or $10 \mu \mathrm{g} / \mathrm{ml}$ cisplatin for $24 \mathrm{~h}, 48 \mathrm{~h}$ and $72 \mathrm{~h}$ respectively. Group 2 was treated with $2 \mu \mathrm{mol} / \mathrm{L}$ $5-\mathrm{AZ}+10 \mu \mathrm{g} / \mathrm{ml}$ paclitaxel, $5-\mathrm{AZ}+18.4 \mu \mathrm{g} / \mathrm{ml}$ docetaxel (Doc), $5-\mathrm{AZ}+25 \mu \mathrm{g} / \mathrm{ml} \mathrm{VP16}$, or $5-\mathrm{AZ}+10 \mu \mathrm{g} / \mathrm{ml}$ cisplatin for $24 \mathrm{~h}, 48 \mathrm{~h}$ and $72 \mathrm{~h}$ respectively. Cell viability was measured at 24, 48 and $72 \mathrm{~h}$ using the Dojindo Cell Counting Kit-8(CCK8 kit, Dojindo Laboratories, Gaithersburg, MD) according to the company's instruction. Absorbance was measured on a microplate reader (Thermo Multiskan MK3 USA) at a wave length of $450 \mathrm{~nm}$.

\section{Flow Cytometry Analysis of Cell Cycle and Apoptosis}

KYSE70, KYSE150 cells were suspended at $5 \times$ $10^{3}$ cells in a $24-$ well plate to $80 \%$ confluence. RPMI 1640 $+10 \%$ FBS medium were used as controls. The treatment groups were treated for $24 \mathrm{~h}$ with RPMI $1640+10 \%$ FBS medium including $0.1 \mu \mathrm{g} / \mathrm{ml} \mathrm{Pac}, 0.1 \mu \mathrm{g} / \mathrm{ml} \mathrm{Pac}+12 \mu \mathrm{mol} / \mathrm{L}$ 5-AZ, $0.2 \mu \mathrm{g} / \mathrm{mL}$ Doc, $0.2 \mu \mathrm{g} / \mathrm{mL}$ Doc $+12 \mu \mathrm{mol} / \mathrm{L}$ 5-AZ, respectively.

Cell cycle was analyzed as described previously [36]. Cells were harvested, fixed in $75 \%$ ethanol, incubated with $100 \mu \mathrm{g} / \mathrm{ml} \mathrm{RNase}$, and stained in $50 \mu \mathrm{g} / \mathrm{ml}$ PI solution. The PI fluorescence was then measured using an EpicsXL MCL flow cytometer (Beckman Coulter Inc., Fullerton, CA, USA). The data were analyzed using Cell Quest software (Becton Dickinson Biosciences).

For apoptosis analysis, Annexin V-FITC/PI Apoptosis Detection Kit (KeyGen Biotechnology, China) was utilized according to the manufacturer's instructions.

\section{Statistical Analysis}

The results are expressed as mean \pm standard deviation (SD). Statistical analysis was performed with
SPSS17.0 software for multiple comparisons. $\chi^{2}$ test and student's test were used. $\mathrm{P}<0.05$ was considered to be statistically significant.

\section{ACKNOWLEDGMENTS}

This work was supported by grants from the National Basic Research Program (973 Program No. 2012CB934002, 2010CB912802), the National Key Scientific instrument Special Programof China (Grant No. 2011YQ03013405), the National High-tech R\&D Program (863 Program No. SS2012AA020314, SS2012AA020821, SS2012AA020303) and the National Science Foundation of China (Grant No. 81121004, 81071953, 81161120432).

\section{REFERENCES}

1. Ferlay J, Shin HR, Bray F, Forman D, Mathers C and Parkin DM. Estimates of worldwide burden of cancer in 2008: GLOBOCAN 2008. International journal of cancer Journal international du cancer. 2010; 127(12):2893-2917.

2. Pennathur A, Gibson MK, Jobe BA and Luketich JD. Oesophageal carcinoma. Lancet. 2013; 381(9864):400-412.

3. Daly JM, Fry WA, Little AG, Winchester DP, McKee RF, Stewart AK and Fremgen AM. Esophageal cancer: results of an American College of Surgeons Patient Care Evaluation Study. Journal of the American College of Surgeons. 2000; 190(5):562-572; discussion 572-563.

4. Hvid-Jensen F, Pedersen L, Drewes AM, Sørensen HT and Funch-Jensen P. Incidence of Adenocarcinoma among Patients with Barrett's Esophagus. New England Journal of Medicine. 2011; 365(15):1375-1383.

5. Guo M, Ren J, House MG, Qi Y, Brock MV and Herman JG. Accumulation of promoter methylation suggests epigenetic progression in squamous cell carcinoma of the esophagus. Clinical cancer research : an official journal of the American Association for Cancer Research. 2006; 12(15):4515-4522.

6. Jankowski JA, Wright NA, Meltzer SJ, Triadafilopoulos G, Geboes K, Casson AG, Kerr D and Young LS. Molecular evolution of the metaplasia-dysplasia-adenocarcinoma sequence in the esophagus. The American journal of pathology. 1999; 154(4):965-973.

7. Li Y, Yang Y, Lu Y, Herman JG, Brock MV, Zhao P and Guo M. Predictive value of CHFR and MLH1 methylation in human gastric cancer. Gastric cancer : official journal of the International Gastric Cancer Association and the Japanese Gastric Cancer Association. 2014.

8. Sarbia M, Geddert H, Klump B, Kiel S, Iskender E and Gabbert HE. Hypermethylation of tumor suppressor genes (p16INK4A, p14ARF and APC) in adenocarcinomas of the upper gastrointestinal tract. International Journal of Cancer. 2004; 111(2):224-228.

9. Baba Y, Watanabe M and Baba H. Review of the alterations 
in DNA methylation in esophageal squamous cell carcinoma. Surgery today. 2013; 43(12):1355-1364.

10. Guo M, Ren J, Brock MV, Herman JG and Carraway HE. Promoter methylation of HIN-1 in the progression to esophageal squamous cancer. Epigenetics : official journal of the DNA Methylation Society. 2008; 3(6):336-341.

11. Jia Y, Yang Y, Brock MV, Cao B, Zhan Q, Li Y, Yu Y, Herman JG and Guo M. Methylation of TFPI-2 is an early event of esophageal carcinogenesis. Epigenomics. 2012; 4(2):135-146.

12. Kaz AM and Grady WM. Epigenetic biomarkers in esophageal cancer. Cancer letters. 2014; 342(2):193-199.

13. Zhang XM and Guo MZ. The value of epigenetic markers in esophageal cancer. Frontiers of medicine in China. 2010; 4(4):378-384.

14. Brock MV, Gou M, Akiyama Y, Muller A, Wu TT, Montgomery E, Deasel M, Germonpre P, Rubinson L, Heitmiller RF, Yang SC, Forastiere AA, Baylin SB and Herman JG. Prognostic importance of promoter hypermethylation of multiple genes in esophageal adenocarcinoma. Clinical cancer research : an official journal of the American Association for Cancer Research. 2003; 9(8):2912-2919.

15. Scolnick DM and Halazonetis TD. Chfr defines a mitotic stress checkpoint that delays entry into metaphase. Nature. 2000; 406(6794):430-435.

16. Yu X, Minter-Dykhouse K, Malureanu L, Zhao WM, Zhang D, Merkle CJ, Ward IM, Saya H, Fang G, van Deursen J and Chen J. Chfr is required for tumor suppression and Aurora A regulation. Nat Genet. 2005; 37(4):401-406.

17. Brandes JC, van Engeland M, Wouters KA, Weijenberg MP and Herman JG. CHFR promoter hypermethylation in colon cancer correlates with the microsatellite instability phenotype. Carcinogenesis. 2005; 26(6):1152-1156.

18. Corn PG, Summers MK, Fogt F, Virmani AK, Gazdar $\mathrm{AF}$, Halazonetis TD and El-Deiry WS. Frequent hypermethylation of the 5' $\mathrm{CpG}$ island of the mitotic stress checkpoint gene $\mathrm{Chfr}$ in colorectal and non-small cell lung cancer. Carcinogenesis. 2003; 24(1):47-51.

19. Honda T, Tamura G, Waki T, Kawata S, Nishizuka S and Motoyama T. Promoter hypermethylation of the Chfr gene in neoplastic and non-neoplastic gastric epithelia. British journal of cancer. 2004; 90(10):2013-2016.

20. Shibata Y, Haruki N, Kuwabara Y, Ishiguro H, Shinoda N, Sato A, Kimura M, Koyama H, Toyama T, Nishiwaki T, Kudo J, Terashita Y, Konishi S, Sugiura H and Fujii Y. Chfr expression is downregulated by $\mathrm{CpG}$ island hypermethylation in esophageal cancer. Carcinogenesis. 2002; 23(10):1695-1699.

21. Derks S, Cleven AH, Melotte V, Smits KM, Brandes JC, Azad N, van Criekinge W, de Bruine AP, Herman JG and van Engeland M. Emerging evidence for CHFR as a cancer biomarker: from tumor biology to precision medicine. Cancer metastasis reviews. 2013.
22. Hamilton JP, Sato F, Greenwald BD, Suntharalingam M, Krasna MJ, Edelman MJ, Doyle A, Berki AT, Abraham JM, Mori Y, Kan T, Mantzur C, Paun B, Wang S, Ito T, Jin Z, et al. Promoter methylation and response to chemotherapy and radiation in esophageal cancer. Clinical gastroenterology and hepatology : the official clinical practice journal of the American Gastroenterological Association. 2006; 4(6):701708.

23. Guo M, House MG, Suzuki H, Ye Y, Brock MV, Lu F, Liu Z, Rustgi AK and Herman JG. Epigenetic silencing of CDX2 is a feature of squamous esophageal cancer. International journal of cancer Journal international du cancer. 2007; 121(6):1219-1226.

24. Banno K, Yanokura M, Kawaguchi M, Kuwabara Y, Akiyoshi J, Kobayashi Y, Iwata T, Hirasawa A, Fujii T, Susumu N, Tsukazaki K and Aoki D. Epigenetic inactivation of the CHFR gene in cervical cancer contributes to sensitivity to taxanes. International journal of oncology. 2007; 31(4):713-720.

25. Pelosof L, Yerram SR, Ahuja N, Delmas A, Danilova L, Herman JG and Azad NS. CHFR silencing or microsatellite instability is associated with increased antitumor activity of docetaxel or gemcitabine in colorectal cancer. International journal of cancer Journal international du cancer. 2014; 134(3):596-605.

26. Ogi K, Toyota M, Mita H, Satoh A, Kashima L, Sasaki Y, Suzuki H, Akino K, Nishikawa N, Noguchi M, Shinomura Y, Imai K, Hiratsuka $\mathrm{H}$ and Tokino T. Small interfering RNA-induced CHFR silencing sensitizes oral squamous cell cancer cells to microtubule inhibitors. Cancer biology \& therapy. 2005; 4(7):773-780.

27. Candelaria M, Gallardo-Rincon D, Arce C, Cetina L, Aguilar-Ponce JL, Arrieta O, Gonzalez-Fierro A, ChavezBlanco A, de la Cruz-Hernandez E, Camargo MF, TrejoBecerril C, Perez-Cardenas E, Perez-Plasencia C, TajaChayeb L, Wegman-Ostrosky T, Revilla-Vazquez A, et al. A phase II study of epigenetic therapy with hydralazine and magnesium valproate to overcome chemotherapy resistance in refractory solid tumors. Annals of oncology : official journal of the European Society for Medical Oncology / ESMO. 2007; 18(9):1529-1538.

28. Guo M, House MG, Hooker C, Han Y, Heath E, Gabrielson E, Yang SC, Baylin SB, Herman JG and Brock MV. Promoter hypermethylation of resected bronchial margins: a field defect of changes? Clinical cancer research : an official journal of the American Association for Cancer Research. 2004; 10(15):5131-5136.

29. Fearon ER and Vogelstein B. A genetic model for colorectal tumorigenesis. Cell. 1990; 61(5):759-767.

30. Vogelstein B, Papadopoulos N, Velculescu VE, Zhou S, Diaz LA, Jr. and Kinzler KW. Cancer genome landscapes. Science. 2013; 339(6127):1546-1558.

31. Balch C, Huang TH, Brown R and Nephew KP. The epigenetics of ovarian cancer drug resistance and resensitization. American journal of obstetrics and 
gynecology. 2004; 191(5):1552-1572.

32. Steinhardt JJ and Gartenhaus RB. Epigenetic approaches for chemosensitization of refractory diffuse large B-cell lymphomas. Cancer discovery. 2013; 3(9):968-970.

33. Sharma SV, Lee DY, Li B, Quinlan MP, Takahashi F, Maheswaran S, McDermott U, Azizian N, Zou L, Fischbach MA, Wong KK, Brandstetter K, Wittner B, Ramaswamy $\mathrm{S}$, Classon $\mathrm{M}$ and Settleman J. A chromatin-mediated reversible drug-tolerant state in cancer cell subpopulations. Cell. 2010; 141(1):69-80.

34. Chaturvedi P, Sudakin V, Bobiak ML, Fisher PW, Mattern MR, Jablonski SA, Hurle MR, Zhu Y, Yen TJ and Zhou BB. Chfr regulates a mitotic stress pathway through its RING-finger domain with ubiquitin ligase activity. Cancer research. 2002; 62(6):1797-1801.

35. Yan W, Wu K, Herman JG, Brock MV, Fuks F, Yang L, Zhu H, Li Y, Yang Y and Guo M. Epigenetic regulation of DACH1, a novel Wnt signaling component in colorectal cancer. Epigenetics. 2013; 8(12):1373-1383.

36. Jia Y, Yang Y, Brock MV, Zhan Q, Herman JG and Guo M. Epigenetic regulation of DACT2, a key component of the Wnt signalling pathway in human lung cancer. J Pathol. 2013; 230(2):194-204.

37. Jia Y, Yang Y, Liu S, Herman JG, Lu F and Guo M. SOX17 antagonizes WNT/beta-catenin signaling pathway in hepatocellular carcinoma. Epigenetics. 2010; 5(8):743749. 